\title{
LACTOBACILLUS STRAINS BELONGING TO CASEI GROUP DISPLAY VARIOUS ADHERENCE TO ENTEROCYTES AND MUCUS ${ }^{*}$
}

\author{
Corinna Markowicz ${ }^{\bowtie}$, Marcin T. Schmidt \\ Department of Food Biotechnology and Microbiology, Poznań University of Life Sciences \\ Wojska Polskiego 28, 60-637 Poznań, Poland
}

\begin{abstract}
Background. The ability of lactobacilli to adhere to the surface of the intestine is an important functional characteristic which can largely determine the effective colonization of the intestinal tract by probiotics. The following study compares the adhesion efficiency of the twenty strains of Lactobacillus genus belonging to Casei group to the Caco-2 cells and gastrointestinal mucus.

Material and methods. Twenty isolates of lactobacilli belonging to Casei group were tested. The ability of bacterial cells to adhere to mucus was examined using adhesion assay to gastrointestinal mucus. Obtained results were compared with adhesion efficiency to Caco-2 cells. Phylogenetic relationship between isolates was analysed by rep-PCR.

Results. The results showed large differences in adhesion efficiency between strains, as well as differences in the efficiency of adhesion to the intestinal epithelial cells and mucus. Group similarity highlighted by a repPCR technique does not correspond with groups of similarity in terms of the characteristics of the ability to adhere to mucus or the epithelial cells of intestinal tract.

Conclusions. Strains having a high adhesion efficiency to enterocytes do not always show a high adhesion efficiency to the mucus. This may indicate the presence of different and multiple factors responsible for adhesion efficiency of Lactobacillus group Casei strains to epithelial cells and mucus.
\end{abstract}

Key words: Lactobacillus, adhesion, mucus, Caco-2, enterocytes, adhesines

\section{INTRODUCTION}

Bacteria of the genus Lactobacillus include many probiotic strains. Many of them belong to the Casei group which includes three species: Lactobacillus casei, Lactobacillus paracasei and Lactobacillus rhamnosus (Felis and Dellagio, 2007). Each probiotic strain, according to the criteria that define this group of microorganisms, must have a beneficial effect on the human organism. It should be derived from the gastrointestinal tract of healthy person and demonstrate the ability to survive extreme environment prevailing in some parts of the gastrointestinal tract (Guidelines..., 2002). A desirable feature of probiotic is also a high efficiency of intestinal colonization, which prolongs the time of its beneficial effect on the host. This is particularly important in relation to the function of immunomodulating effect of probiotics and its antagonism with respect to pathogenic microorganisms (Grangette et al., 2005; Hisbergues et al., 2007). Bacteria can colonize

\footnotetext{
\corinna.markowicz@gmail.com, phone +48 602462 444, fax +48 618466003

*This work was supported by the Polish National Science Centre grant no. N N312 272640 in years 2011-2014. 
the intestine where they can settle on the surface of the intestinal epithelium. Essential for successful colonization is occurrence of the phenomenon of adhesion. Multiple physical and chemical agents are involved in the process of adhesion. The process relies on macromolecules anchored to the cell surface and secreted outside the cells. Bacteria of the genus Lactobacillus are able to adhere directly to the surface of epithelial cells and/or mucus produced by them. Adhesins responsible for binding to molecules present on the surface of enterocytes are, for example, collagen binding protein $\mathrm{CbsA}$ or fironectin binding protein $\mathrm{FbpA}$ (Antikainen et al., 2002; Buck et al., 2005). Adhesion to intestinal mucus occurs with the participation of adhesins such as mucin binding proteins (Roos and Jonsson, 2002), or certain polysaccharides associated with the bacterial cell wall or secreted into the external environment (Darilmazl et al., 2011). SpaCBA protein complex forming fimbriae on the surface of bacterial cells is responsible for the adhesion to both mucus and enterocytes (Kankainen et al., 2009; Reunanen et al., 2012). The adhesion efficiency of different strains may show considerable differences, affecting the efficiency of beneficial effect of the probiotic.

The aim of this study was to analyse whether the adhesion efficiency of Lactobacillus group Casei to either enterocytes or gastrointestinal mucus is phylogenetically related trait.

\section{MATERIAL AND METHODS}

Bacterial strains. Twenty strains of Lactobacillus belonging to the Casei group were obtained from the culture collection of the Department of Biotechnology and Food Microbiology of Poznań University of Life Sciences (Table 1). Tested strains were derived from dietary supplements and humans' feces. Bacterial cultures were propagated in MRS liquid medium (Biocorp, Poland), at $37^{\circ} \mathrm{C}$, under anaerobic conditions. Bacteria were cultured in Gene Box (Biomerieux, Poland) designed for the anaerobic microorganisms culture. AnaeroGen (Thermo Scientific, Poland) anaerobic atmosphere generators were used to obtain anaerobic conditions.

Isolation of bacterial exopolysaccharides. Bacterial strains were growth in liquid MRS medium for $18-20$ hours, at $37^{\circ} \mathrm{C}$ in anaerobic conditions. $50 \mu 1$ of bacterial cultures was plated into Petri dishes and cultured for 72 hours (at $37^{\circ} \mathrm{C}$ in anaerobic conditions). After this time, bacterial colonies were washed from the plates with water. OD of bacterial suspensions was standardized. Suspensions were mixed with $1 \mathrm{M} \mathrm{NaOH}$ (1:1) and incubated over night (room temperature, gentle shaking). After incubation, bacterial suspensions were centrifuged (13 $000 \mathrm{rpm}, 1 \mathrm{~min})$. Supernatants were mixed with ice-cold ethanol (1:2), exopolysaccharides were precipitated for 72 hours at $4^{\circ} \mathrm{C}$. After this time, exopolysaccharides were centrifuged (13 $000 \mathrm{rpm}, 10 \mathrm{~min}$ ), supernatant was throw out and polysaccharides were air-dried for 20 minutes. After drying they were frozen at $-80^{\circ} \mathrm{C}$.

\section{Polyacrylamide gel electrophoresis and staining of} exopolysaccharides. Polyacrylamide gel electrophoresis of bacterial exopolysaccharides was prepared according to Maniatis et al. (1975). The acrylamide stock solution contained $20 \%(\mathrm{w} / \mathrm{v})$ acrylamide and $0.67 \%$ NN'-methylenebisacrylamide. Concentrated electrophoretic buffer contained $0.2 \mathrm{M}$ Tris/borate/0.002Mdisodium EDTA, pH $8.3(2 \times$ Tris/borate/EDTA). Equal volumes of these solutions were mixed at room temperature. For polymerization, $0.4 \mathrm{ml}$ of $10 \%(\mathrm{w} / \mathrm{v})$ ammonium persulphate in water and $0.04 \mathrm{ml}$ of NNN'N'tetramethylethylenediamine were added per $100 \mathrm{ml}$ of gel solution. The gels were cast between glass plates. The gels were polymerized overnight at room temperature. $10 \mu 1$ of each polysaccharide sample was mixed $1: 1$ with $2 \mathrm{M}$-sucrose and $0.2 \%$ bromophenol blue in $1 \times$ Tris/borate/EDTA buffer and applied to the well. Gels were electrophoresed at $20 \mathrm{~mA}$ for $20 \mathrm{~min}$ and then at $40 \mathrm{~mA}$ for $1.5 \mathrm{~h}$ in $1 \times$ Tris/borate/EDTA buffer. Precision Plus Protein ${ }^{\mathrm{TM}}$ All Blue Standard (Bio Rad, Poland) was used to estimate molecular mass of exopolysaccharides. After electrophoresis, gels were stained according to Cowman et al. (1984). The gels were stained in $0.5 \%$ alcian blue in $2 \%$ acetic acid for $45 \mathrm{~min}$, then destained for $15 \mathrm{~min}$ in $2 \%$ acetic acid.

Adhesion of tested strains to the Caco-2 cells. Adhesion assay was performed as described previously (Schmidt et al., 2010), briefly: bacterial cells were grown in MRS broth (Biocorp) at $37^{\circ} \mathrm{C}$ in anaerobic conditions with methyl-[3H]-thymidyne $(5 \mu \mathrm{l} / \mathrm{ml}$ of broth, $60-90 \mathrm{Ci} / \mathrm{mmol}, 1 \mathrm{mCi} / \mathrm{ml}$; Hartmann Analytic 
Markowicz, C., Schmidt, M. T. (2015). Lactobacillus strains belonging to Casei group display various adherence to enterocytes and mucus. Acta Sci. Pol. Technol. Aliment., 14(3), 247-255. DOI: 10.17306/J.AFS.2015.3.26

Table 1. Bacterial strains used in this study

\begin{tabular}{lll}
\hline Isolate & \multicolumn{1}{c}{ Species } & \multicolumn{1}{c}{ Source } \\
\hline DS5 & L. casei & Yacult probiotic drink, Yacult Europe, The Netherlands \\
DS8 & L.casei & Fyos probiotic drink, Nutricia, Belgium \\
HI2 & L. casei & Human stool isolate \\
HI3 & L. casei & Human stool isolate \\
HI6 & L. casei & Human stool isolate \\
HI7 & L. casei & Human stool isolate \\
DS6 & L.paracasei & Latopic probiotic supplement, Biomed-Krakow, Poland \\
HI1 & L.paracasei & Human stool isolate \\
DS1 & L.rhamnosus & Lactoral probiotic supplement, Biomed-Krakow, Poland \\
DS2 & L.rhamnosus & Dicoflor probiotic supplement, Vitis Pharma, Poland \\
DS3 & L.rhamnosus & Ellen probiotic tampon, Ellen AB, Sweden \\
DS7 & L.rhamnosus & Ecovag probiotic supplement, Krotex, Poland \\
DS9 & L.rhamnosus & Lakcid probiotic supplement, Biomed-Lublin, Poland \\
DS10 & L.rhamnosus & Lactovaginal probiotic supplement, Biomed-Krakow, Poland \\
DS11 & L.rhamnosus & Lacibios probiotic supplement, ASA, Poland \\
DS12 & L.rhamnosus & Lakcid probiotic supplement, Biomed-Lublin, Poland \\
DS13 & L.rhamnosus & Lakcid probiotic supplement, Biomed-Lublin, Poland \\
DS14 & L.rhamnosus & Latopic probiotic supplement, Biomed-Krakow, Poland \\
HI4 & L.rhamnosus & Human stool isolate \\
HI5 & L.rhamnosus & Human stool isolate \\
\hline & &
\end{tabular}

GmbH, Germany). After 18-20 hours of growth, the bacteria were washed twice with sterile Hank's buffered salts solution (HBSS) and resuspended in the same buffer. Caco-2 cells (passage no. 49-52) used in the adhesion assay were prepared in PTFE filter $(0.4 \mu \mathrm{m}$ pore size) inserts for 6-well tissue-culture dishes (Merck-Millipore, Poland) by inoculating $4 \cdot 10^{5}$ cells $/ \mathrm{cm}^{2}$. Twenty one-day-post-confluent Caco-2 cell monolayers were washed with $1 \mathrm{ml}$ HBSS then bacteria at concentrations of approximately $5 \cdot 10^{8} \mathrm{cfu} / \mathrm{ml}$ were added to each well in $2.0 \mathrm{ml}$ (total volume) HBSS and incubated at $37^{\circ} \mathrm{C}$ in an atmosphere of $10 \%(\mathrm{v} / \mathrm{v})$ $\mathrm{CO}_{2}$ in air. After 60 min incubation, monolayers were washed three times with sterile, HBSS to remove free bacterial cells. The amount of adhered bacterial cells was estimated from the radioactivity remaining at the Caco-2 monolayer. Each assay was performed in triplicate. Radiolabelled bacteria in amount initially added for adhesion and washed Caco-2 monolayer with adhered radiolabelled bacteria were lysed in $0.9 \mathrm{ml}$ of $1 \%$ SDS, then $0.1 \mathrm{ml}$ of $1 \mathrm{M} \mathrm{NaOH}$ was added and the lysate was incubated overnight at $60^{\circ} \mathrm{C}$ to complete lysis. The radioactivity of the lysed suspension was measured by liquid scintillation in Beckmann LS6500 after addition of Hionic-Fluor scintillation cocktail (Perkin-Elmer, Poland).

Adhesion of tested strains to the gastrointestinal mucus. The lyophilized gastrointestinal mucus (cat no. M1778, Sigma-Aldrich) was dissolved in PBS with calcium and magnesium ions to concentration of $0.1 \mathrm{~g} /$ ml. Maxi Sorp 96-well plates (cat no. 436110, Nunc) were coated with mucus solution overnight at $4^{\circ} \mathrm{C}$, then washed twice with $300 \mathrm{ml}$ of Hank's balanced salt 
solution (HBSS). Bacterial cultures were washed twice with PBS with calcium and magnesium ions. Bacterial suspension $\left(50 \mu \mathrm{l}\right.$ with a density of $\left.5 \cdot 10^{8} \mathrm{cfu} / \mathrm{ml}\right)$ was applied to the wells. Incubation was carried out for 1 hour at $37^{\circ} \mathrm{C}$. After incubation, wells were washed twice with HBSS and then, $100 \mathrm{ml}$ of HBSS was loaded onto each well. The amount of bacteria adhered to the mucus was determined using BAC-Titer-Glo Microbial Cell Viability Assay (Promega). The measurement of the luminescence intensity was performed using the Infinite M200 reader (Tecan).

Extraction of DNA from bacteria. DNA from bacterial cultures was isolated with Genomic Mini Kit (A\&A Biotechnology, Poland) according to the manufacturer instruction.

Rep-PCR. PCR reactions were performed using two sets of primers: REP (REP1R: 5'IIIICGICGICATCIGGC; REP2I: 5'ICGICTTATCIGGCCTAC) and ERIC (ERIC1R: 5'ATGTAAGCTCCTGGGGATTCAC; ERIC2: 5'AAG TAAGTGACTGGGGTGAGCG) detecting the repetitive sequences in the bacterial genome. The reaction contained 50 ng genomic DNA, $1.5 \mathrm{U}$ polymerase (Run Polymerase A\&A Biotechnology), 1× reaction buffer, $200 \mathrm{uM}$ each of deoxyribonucleotide triphosphates, and $0.5 \mathrm{mM}$ of each primer. Initial denaturation was performed at $95^{\circ} \mathrm{C}$ for $1 \mathrm{~min}$, followed by 35 cycles of: denaturation, $95^{\circ} \mathrm{C}, 1 \mathrm{~min}$, annealing, $40^{\circ} \mathrm{C}$ (for REP primer), $42^{\circ} \mathrm{C}$ (for ERIC primer) for $1 \mathrm{~min}$, and elongation $72^{\circ} \mathrm{C}, 4 \mathrm{~min}$. Final elongation was performed at $72^{\circ} \mathrm{C}$ for $8 \mathrm{~min}$. Separation of the PCR products was carried out in 2\% agarose gel, stained with ethidium bromide. Gel images were analysed using Quantity One (Bio-Rad). The similarity between isolates (based on their genetic fingerprints) was calculated based on the Dice coefficient, UPGMA method and expressed graphically as a dendrogram using Data Assist $^{\mathrm{TM}}$ v3.01 Software (Life Technologies).

\section{RESULTS AND DISCUSSION}

Lactobacillus strains have differentiated capacity to adhere to gastrointestinal mucus. The ability of bacterial cells to adhere to mucus is expressed as the percentage of cells that adhered to the surface of a well coated by gastrointestinal mucus (bacteria which have not been washed off during the rinse step). Adhesion efficiency to gastrointestinal mucus ranged from $91 \%$ to less than $1 \%$ (Fig. 1). Two isolates from human stool showed very high adhesion to mucus of $91 \%$ ( $L$. casei HI 3 ) and $75 \%$ (L. casei HI2). Three strains from dietary supplements (L. rhamnosus DS1, L. rhamnosus DS2, L. paraceasei DS6) and one isolate from stool (L. rhamnosus HI5) showed medium adhesion efficiency (between $46 \%$ and $25 \%$ ). The average capacity to adhere to gastrointestinal mucus characterised strains L. rhamnosus DS10 (10\%), L. casei DS8 (9\%), L. rhamnosus DS9 (6\%), and L. paracasei HI1 (6\%), low capacity to adhere to gastrointestinal mucus characterised L. rhamnosus HI4 (3\%), L. casei HI6, L. rhamnosus DS3 and DS11 (2\%). The remaining strains were characterised by a very low capacity to adhere or total lack of this feature (value of less than $1 \%$ of adhered cells).

Analysis of the phylogenetic relationship between tested isolates. Phylogenetic relationship between isolates was analysed by rep-PCR (Versalovic et al., 1994). This technique uses the primers binding to repeated sequences in bacterial genome. Amplicons obtained in the reaction forms patterns specific for individual strains. Used oligonucleotide primers generated 41 polymorphic bands, that allowed to determine the genetic similarity between tested isolates. Dendrogram of similarity (Fig. 2) showed that the largest range of diversity in analysed group of 20 isolates, characterized isolates belonging to L. rhamnosus species. Genetic fingerprints of L. rhamnosus DS12 and DS14 isolates were characterised by the highest coefficient of the identity at the level of 0.83 . Fingerprint of $L$. rhamnosus DS9 isolate was characterised by a factor of 0.07 of identity in relation to other tested isolates. Whereas L. paracasei HI1 and DS6 isolates showed low genetic similarity coefficient of 0.25 . The largest interspecific genetic similarity with the value of 0.68 was observed between L. casei (DS8, HI6, HI3) and L. rhamnosus DS7 isolates.

The relationship between adhesion to enterocytes, gastrointestinal and genetic similarity. In the group of tested isolates, there can be distinguished strains with large (L. rhamnosus DS1, L. rhamnosus DS2, L. paracasei $\mathrm{HI} 1, L$. casei $\mathrm{HI}$, L. casei $\mathrm{HI} 3$, L. rhamnosus HI5) and moderate (L. rhamnosus DS3, L. paracasei 


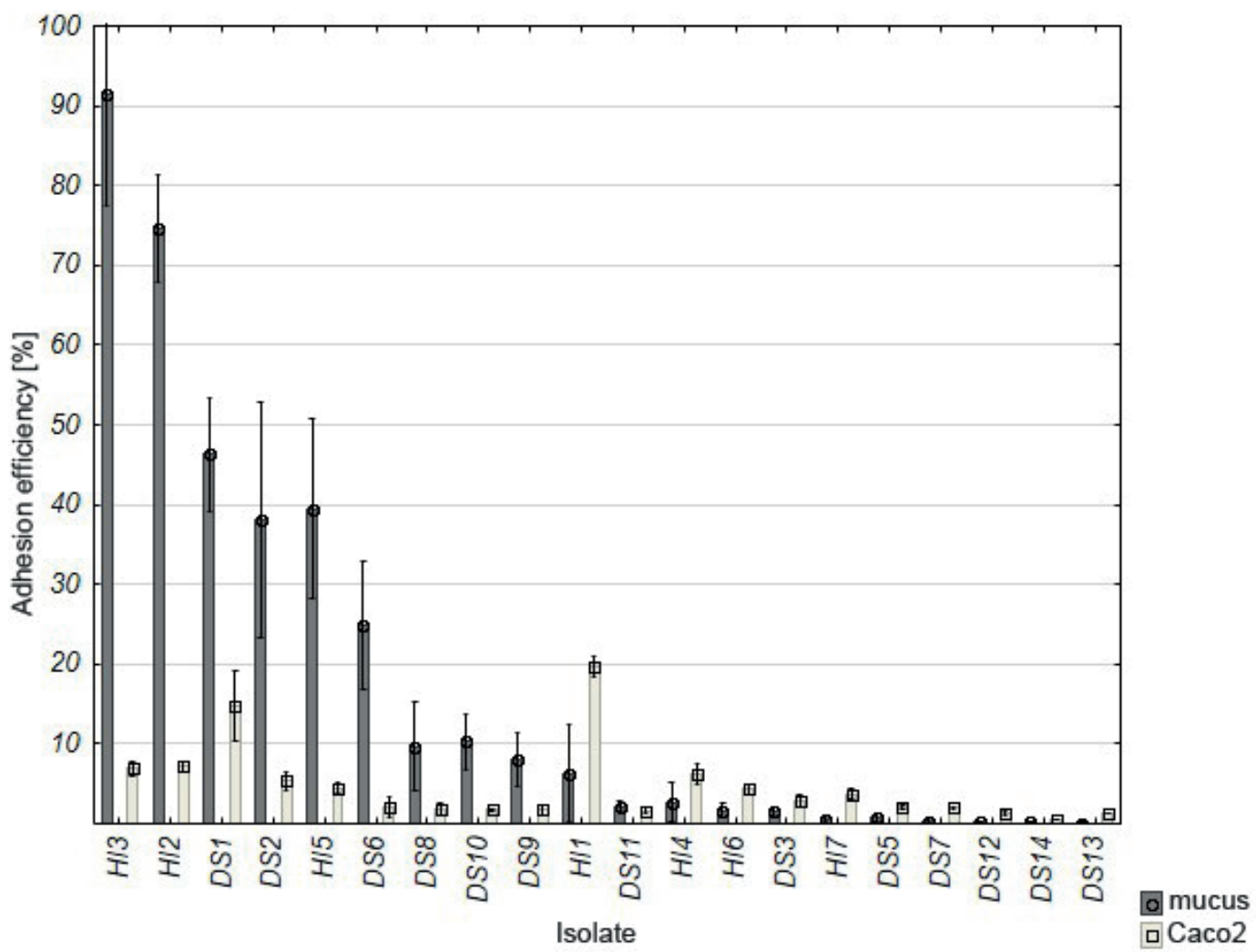

Fig. 1. Comparison of capacity of Lactobacillus isolates belonging to Casei group adherence to mucus (gray bars) and Caco-2 cells (white bars) and intestinal mucus. Bars represent average values of three measurements and whiskers represent the mean values $\pm 1.5 \times$ standard deviation.

DS6, L. casei DS8, L. rhamnosus DS9, L. rhamnosus DS10, L. rhamnosus DS11, L. rhamnosus HI4, L. casei HI6) ability to adhere to both mucus and epithelial cell surface. These two groups have the potential to colonize the human gastrointestinal tract because of the ability to adhere to the surface of the intestines (small and large). Isolates (L. casei $\mathrm{HI} 7$, L. casei DS5, L. rhamnosus DS7) having the ability to adhere to the enterocytes (but not to the mucus) can only interact with the surface of the small intestine or in pathological cases, where the mucus layer is absent on the surface of colon. Strains characterised by weak ability of adhesion to enterocytes and mucus (L. rhamnosus DS12, L. rhamnosus DS13, L. rhamnosus DS14) are transit microflora with short impact on the intestinal environment. Their influence will refer mainly to the intestinal microbiome. Knowledge about these characteristics in relation to probiotic and industrial strains allows to make a better selection of strain to the expected functionality of the product (food or dietary supplement).

Comparing the Lactobacillus Casei group isolates adhesion efficiency to mucus and enterocytes (Caco-2 cells) showed the convergence only in some strains. The ability of tested isolates to adhere to mucus may be at least 4.5 times higher ( $91 \%$ of the cells of $L$. casei HI3) in comparison to adhesion efficiency to enterocytes $(20 \% \mathrm{~L}$. paracasei HI 1$)$. The ability to adhere to mucus and enterocytes is characterised by the Pearson correlation coefficient of $R=0.346$. This suggests that the feature of adhesion to these two substrates is conditioned by various factors. This may be caused by presence of a variety molecules on the surface of enterocytes, which can be bound by different types of adhesins present on the surface of bacterial cells. In contrast, the potential number of adhesins involved in mucus binding process is much smaller. 
The differences in the efficiency of adhesion to the enterocytes and mucus may also result from the nature of the interactions between bacterial and epithelial cells. It has been proven that in the process of adhesion to the mucus, electrostatic interactions plays a significant role. However their stability is low and they can easily rupture under the influence of chemical and mechanical properties (Sun et al., 2007). In addition, different strains of the genus Lactobacillus may synthesize different exopolysaccharides in various amounts. These are substances that affect the efficiency of adhesion of bacteria to the intestinal epithelium, however, depending on their type and concentration, the impact can be positive or negative (Landersjo et al., 2002; Ruas-Madiedo et al., 2006). Exopolysaccharide layer of the bacterial cell surface may also impede the interaction between the other adhesins present on the surface of bacterial cells, and the environment. Tested strains have ability to produce different amounts of exopolysaccharides (Fig. 2).

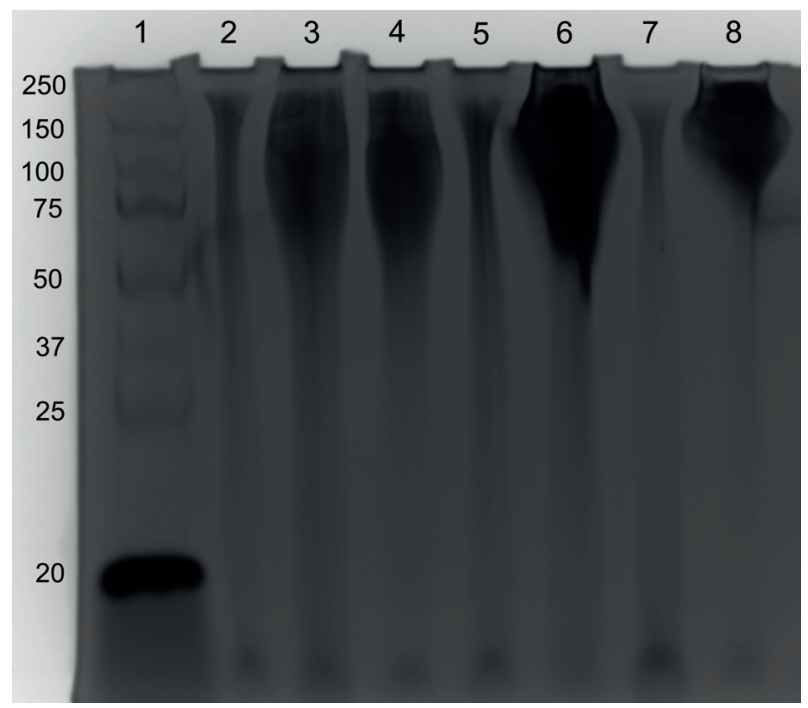

Fig. 2. Polyacrylamide gel electrophoresis of exopolysaccharides isolated from Lactobacillus strains. Lane 1 - molecular weight marker, lane 2 to 8 - exopolysaccharides isolated from: 2 - Lactobacillus rhamnosus (DS2), 3 - Lactobacillus rhamnosus (DS1), 4 - Lactobacillus casei (HI7), 5 - Lactobacillus casei (HI2), 6 - Lactobacillus paracasei (HI1), 7 - Lactobacillus casei (DS5), 8 - Lactobacillus casei (DS8)
The results obtained in this study were compared with those obtained in previous work of Markowicz et al. (2014) concerning the variation of spaCBA adhesive protein coding sequence. Most of the isolates showing high and average ability to adhere to mucus contains complete coding sequence structural proteins (spaC, spaB, spaA). They form a polymeric fimbriae, which participation in the process of adhesion to the intestinal epithelium has been previously demonstrated. They also have the ability to bind to the mucus, through the presence of the subunit $\mathrm{SpaC}$ mucus binding domain (Kankainen et al., 2009; Reunanen et al., 2012). Another factor differentiating ability of individual strains to adhere to the intestinal epithelium are variations in the sequences encoding the fimbrial protein structure (Toh et al., 2013) and its expression (Douillard et al., 2013; Rasinkangas et al., 2014). The spaCBA complete coding sequence is present in $L$. paracasei DS6 and L. casei DS8 isolates but the protein is not expressed (Markowicz et al., 2014). These strains, however, showed the ability to adhere to mucus respectively, $25 \%$ and $10 \%$. In contrast, isolate DS10 which does not have the coding sequence of the spaCBA protein (Markowicz et al., 2014), is characterised by $10 \%$ of the ability to adhere to mucus. These data confirm that the ability to adhere to enterocytes and mucus is depend on different factors. There was no clear relationship between the phylogenetic similarity of tested strains and their ability to adhere to enterocytes and gastrointestinal mucus (Fig. 3). However, it can be seen that the strains isolated from faeces display better adhesion efficiency to the enterocytes than strains derived from dietary supplements. Such dependence has been indicated also on a larger sample of bacterial strains by Douillard et al. (2013). Four of the six strains expressing spaCBA were strains isolated from feces. The presence of such correlations may indicate environmental influence on enhancing adhesion efficiency to enterocytes. In bacteria without contact with the intestinal epithelium these abilities decrease. In this study, no clear relationship between the origin of the strain and the efficiency of adhesion to gastrointestinal mucus can be seen.

Primers used in rep-PCR technique, following by literature data are very useful in differentiating isolates within one species of bacteria (Versalovic et al., 1994). Comparison of genetic fingerprints of tested isolates 
Markowicz, C., Schmidt, M. T. (2015). Lactobacillus strains belonging to Casei group display various adherence to enterocytes and mucus. Acta Sci. Pol. Technol. Aliment., 14(3), 247-255. DOI: 10.17306/J.AFS.2015.3.26

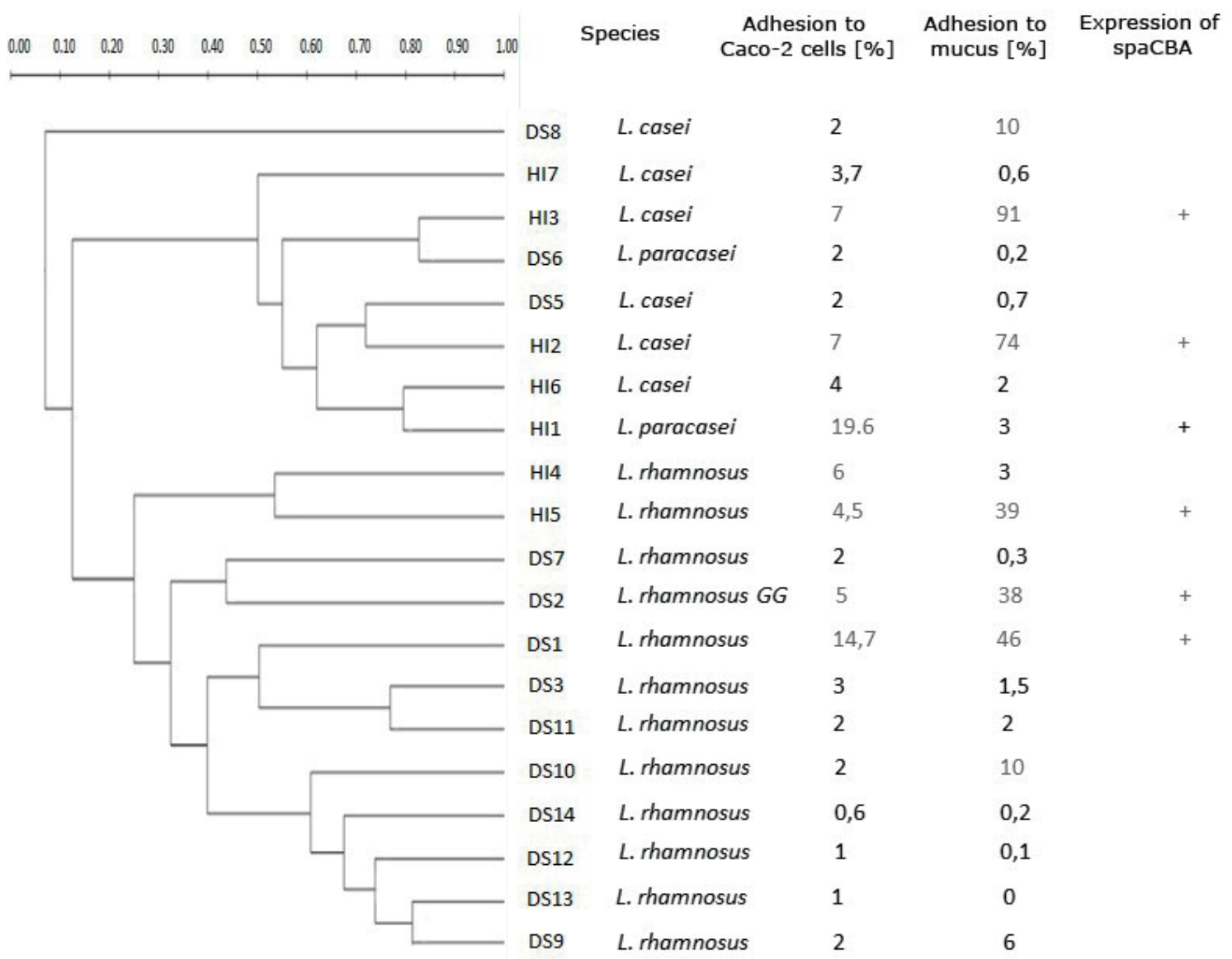

Fig. 3. Relationship between adhesion to enterocytes and gastrointestinal mucus, presence of spaCBA surface protein (data obtained in previous work of Markowicz et al. (2014)) and genetic similarity of lactobacilli strains. Dendrogram of genetic similarity between the tested human stool isolates (HI1-HI7) and dietary supplements isolates (DS1-DS13) of lactobacilli belonging to Casei group. The phylogenetic tree was obtained on the basis of genetic fingerprints of studied isolates, using the REP and ERIC primers, based on the Dice coefficient using the UPGMA method. The scale and value of the nodes describe the similarity of isolates

confirmed the close genetic relationship of species: $L$. casei, L. rhamnosus and L. paracesei belonging to the Casei group (Felis and Dellaglio, 2007).

\section{CONCLUSIONS}

Tested strains of lactobacilli belonging to Casei group have different adhesion efficiency to Caco-2 cells and gastrointestinal mucus. High level of adhesion efficiency can decide about enhanced ability to colonize the gastrointestinal tract and prolonged impact on the intestinal environment. Strains having a high adhesion efficiency to enterocytes do not always have a high adhesion efficiency to the mucus. This may indicate the presence of different and multiple factors responsible for adhesion to epithelial cells and mucus, including exopolysaccharides. There may also occur interactions between various adhesive agents, which can change the efficiency of bacterial adhesion. The presence of complete and unchanged sequence coding spaCBA protein complex in some bacterial strains has a positive effect on their adhesion efficiency. These studies indicated that the group similarity highlighted by a rep-PCR technique do not correspond with 
groups of similarity in terms of the characteristics of the ability to adhere to mucus or the epithelial cells of intestinal tract. In order to obtain a broader picture of the relationship between the ability to adhere to the intestinal epithelium, and variety of genomic nucleotide sequences of the lactobacilli from Casei group, it is necessary to analyse a larger number of isolates of diverse origin.

\section{REFERENCES}

Antikainen, J., Anton, L., Sillanpaa, J., Korhonen, T. K. (2002). Domains in the S-layer protein CbsA of Lactobacillus crispatus involved in adherence to collagens, laminin and lipoteichoic acids and in self-assembly. Mol. Microbiol., 46, 2, 38-394.

Buck, B. L., Altermann, E., Svingerud, T., Klaenhammer, T. R. (2005). Functional analysis of putative adhesion factors in Lactobacillus acidophilus NCFM. Appl. Environ. Microbiol., 71, 12, 8344-8351.

Cowman, M. K., Slahetka, M. F., Hittner, D. M., Kim, J., Forino, M., Gadelrab, G. (1984). Polyacrylamide-gel electrophoresis and Alcian Blue staining of sulphated glycosaminoglycan oligosaccharides. Biochem. J., 221, 3, 707-716.

Darilmazl, D. O., Aslim, B., Suludere, Z., Akca, G. (2011). Influence of gastrointestinal system conditions on adhesion of exopolysaccharide-producing Lactobacillus delbrueckii subsp. bulgaricus strains to Caco-2 Cells. Braz. Arch. Biol. Technol., 54, 5, 917-926.

Douillard, F. P., Ribbera, A., Järvinen, H. M., Kant, R., Pietilä, T. E., Randazzo, C., ..., de Vos, W. M. (2013). Comparative genomic and functional analysis of Lactobacillus casei and Lactobacillus rhamnosus strains marketed as probiotics. Appl. Environ. Microbiol., 79, 6, 1923-1933.

Douillard, F. P., Ribbera, A., Kant, R., Pietila, T. E., Jarvinen, H. M., Messing, M., ..., de Vos, W. M. (2013). Comparative genomic and functional analysis of 100 Lactobacillus rhamnosus strains and their comparison with strain GG. PLOS Genet., 9, 8, 1-15.

Felis, G. E., Dellaglio, F. (2007). Taxonomy of lactobacilli and bifidobacteria. Curr. Issues Intest. Microbiol., 8, 2, 44-61.

Grangette, C., Nutten, S., Palumbo, E., Morath, S., Hermann, C., Dewulf, J., ..., Mercenier, A. (2005). Enhanced anti-inflammatory capacity of a Lactobacillus plantarum mutant synthesizing modified teichoic acids. Proc. Natl. Acad. Sci. USA, 102, 29, 10321-10326.
Guidelines for the evaluation of probiotics in food. Report of a Joint FAO/WHO Working Group on Drafting Guidelines for the Evaluation of Probiotics in Food. (2002). London, Ontario, Canada.

Hisbergues, M., Magi, M., Rigaux, P., Steuve, J., Garcia, L., Goudercourt, D., ..., Jacquet, A. (2007). In vivo and in vitro immunomodulation of Der $\mathrm{p} 1$ allergen-specific response by Lactobacillus plantarum bacteria. Clin. Exp. Allergy, 37, 9, 1286-1295.

Kankainen, M., Paulina, L., Tynkkynenb, S., Von Ossowskic, I., Reunanenc, J., Partanena, P., ..., De Vos, W. M. (2009). Comparative genomic analysis of Lactobacillus rhamnosus GG reveals pili containing a human mucus binding protein. PNAS, 106, 40, 17193-17198.

Landersjo, C., Yang, Z., Huttunen, E., Widmalm, G. (2002). Structural studies of the exopolysaccharides produced by Lactobacillus rhamnosus strain GG (ATCC 53103). Biomacromolecules, 3, 4, 880-884.

Maniatis, T., Jeffrey, A., van deSande, H. (1975). Chain length determination of small double- and single-stranded DNA molecules by polyacrylamide gel electrophoresis. Biochemistry, 14, 17, 3787-3794.

Markowicz, C., Olejnik-Schmidt, A., Borkowska, M., Schmidt, M. T. (2014). SpaCBA sequence instability and its relationship to the adhesion efficiency of Lactobacillus casei group isolates to Caco-2 cells. Acta Biochim. Pol., 61, 2, 341-347.

Rasinkangas, P., Reunanen, J., Douillard, F. P., Ritari, J., Uotinen, V., Palva, A., de Vos, W. M. (2014). Genomic characterization of non-mucus adherent derivatives of Lactobacillus rhamnosus GG reveals genes affecting pilus biogenesis. Appl. Environ. Microbiol., 80, 22, 7001-7009.

Reunanen, J., von Ossowski, I., Hendrickx, A. P. A., Palva, A., de Vos, W. M. (2012). Characterization of the spaCBA pilus fibers in the probiotic Lactobacillus rhamnosus GG. App. Environ. Microbiol., 78, 7, 2337-2344.

Roos, S., Jonsson, H. (2002). A high-molecular-mass cellsurface protein from Lactobacillus reuteri 1063 adheres to mucus components. Microbiology, 148, 2, 433-442.

Ruas-Madiedo, P., Gueimonde, M., Margolles, A., de los Reyes-Gavilan, C. G., Salminen, S. (2006). Exopolysaccharides produced by probiotic strain modify the adhesion of probiotics and enteropathogens to human intestinal mucus. J. Food Prot., 69, 8, 2011-2015.

Schmidt, M. T., Olejnik-Schmidt, A. K., Myszka, K. Borkowska, M., Grajek, W. (2010). Evaluation of quantitative PCR measurement of bacterial colonization of epithelial cells. Pol. J. Microbiol., 59, 2, 83-93. 
Markowicz, C., Schmidt, M. T. (2015). Lactobacillus strains belonging to Casei group display various adherence to enterocytes and mucus. Acta Sci. Pol. Technol. Aliment., 14(3), 247-255. DOI: 10.17306/J.AFS.2015.3.26

Sun, J., Le, G. W., Shi, Y. H., Su, G. W. (2007). Factors involved in binding of Lactobacillus plantarum Lp6 to rat small intestinal mucus. Lett. Appl. Microbiol., 44, 1, $79-85$.

Toh, H., Oshima, K., Nakano, A., Takahata, M., Murakami, M., Takaki, T., ..., Morita, H. (2013). Genomic adaptation of the Lactobacillus casei group. PLoS One, 8, 10, e75073.

Versalovic, J., Schneider, M., De Bruijn, F. J., Lupski, J. R. (1994). Genomic fingerprinting of bacteria using repetitive sequence-based polymerase chain reaction. Meth. Molec. Cell. Biol., 5, 25-40.

\section{ZRÓŻNICOWANIE ZDOLNOŚCI BAKTERII Z RODZAJU LACTOBACILLUS NALEŻĄCYCH DO GRUPY CASEI DO PRZYLEGANIA DO ENTEROCYTÓW I ŚLUZU PRZEWODU POKARMOWEGO}

\section{STRESZCZENIE}

Zdolność bakterii Lactobacillus z grupy Case do przylegania do powierzchni jelit jest istotną cechą funkcjonalną, która w znacznym stopniu może decydować o skuteczności probiotyku. W proces adhezji są zaangażowane liczne czynniki obecne na powierzchni komórek bakteryjnych oraz nabłonka jelitowego. Złożony charakter zjawiska adhezji sprawia, że dokładne poznanie jego mechanizmów jest trudne i wymaga licznych badań. W pracy porównano wydajność adhezji dwudziestu szczepów bakterii Lactobacillus z grupy Casei do komórek Caco-2 oraz do śluzu przewodu pokarmowego. Uzyskane wyniki wykazały duże zróżnicowanie wydajności adhezji między poszczególnymi szczepami, jak również różnice w wydajności adhezji bakterii do komórek nabłonkowych jelit i śluzu.

Słowa kluczowe: Lactobacillus, przyleganie, Caco-2, enterocyty, śluz, adhezyny

For citation - Do cytowania

Markowicz, C., Schmidt, M. T. (2015). Lactobacillus strains belonging to Casei group display various adherence to enterocytes and mucus. Acta Sci. Pol. Technol. Aliment., 14(3), 247-255. DOI: 10.17306/J.AFS.2015.3.26 